FACTA UNIVERSITATIS

Series: Physical Education and Sport, Vol. 17, No 1, 2019, pp. 69 - 78

https://doi.org/10.22190/FUPES190310009M

Research article

\title{
DIFFERENCES IN VISUAL REACTION CHARACTERISTICS IN NATIONAL LEVEL CADET AND JUNIOR FEMALE HANDBALL PLAYERS
}

UDC 796.322:628.976

\section{Stefan Marković ${ }^{1}$, Zoran Valdevit ${ }^{1}$, Marta Bon ${ }^{2}$, Ljubomir Pavlović $^{3}$, Jelena Ivanović ${ }^{4}$, Milivoj Dopsaj ${ }^{1,5}$}

${ }^{1}$ Faculty of Sport and Physical Education, University of Belgrade, Belgrade, Serbia

${ }^{2}$ Faculty of Sport, University of Ljubljana, Ljubljana, Slovenia

${ }^{3}$ Faculty of Sport and Physical Education, University of Niš, Niš, Serbia

${ }^{4}$ Serbian Institute of Sport and Sports Medicine, Belgrade, Serbia

${ }^{5}$ South Ural State University, Institute of Sport, Tourism and Service, Chelyabinsk, Russia

\begin{abstract}
This paper aims to define differences in Simple Visual Reaction Time (SVRT) and Reaction Time Variation (RTV), related to age and player position in Serbian female cadet and junior national handball team members. The method used in this research was laboratory testing. All data sampling was performed using specially designed testing software that recorded visual reaction time with $1 \mathrm{~ms}$ precision. SVRT was expressed in ms, and RTV was expressed as a coefficient of variation percentage value. The overall sample consisted of 34 players - 19 cadets and 15 juniors. Mean SVRT of 194.28 \pm 16.55 and $184.73 \pm 16.68 \mathrm{~ms}$ was determined in the subsamples of cadet and junior players, respectively. It was found that cadets have a mean RTV of $4.74 \pm 2.41 \%$ while juniors have a mean RTV of $7.90 \pm 3.70 \%$. Results of the Factorial ANOVA have shown that there are no general, statistically significant, differences in SVRT in relation to age, player position, and interaction of these factors ( $p>0.05)$. Statistically significant difference in RTV on a general level was found in relation to age $(F=9.752, p=0.005)$, while differences in relation to player position or combination of these factors were not statistically significant $(p>0.05)$. Post hoc tests have shown partial differences in relation to player position. The method of mathematical modelling was used to define the statistical model of performance in relation to the given variables. The final form of the model explained 100\% of the measured variance $($ AdjR2 = 1.000), which implies its absolute predictive potential considering the characteristics of the sample.
\end{abstract}

Key words: Handball, Reaction time, Concentration, Age category

Received March 10, 2019 / Accepted April 08, 2019

Corresponding author: Stefan Marković

University of Belgrade, Faculty of Sport and Physical Education, Blagoja Parovića 156, 11000 Belgrade, Serbia Phone: +381 113531000 •E-mail: stephan.markovic@ hotmail.com 


\section{INTRODUCTION}

Handball is a strenuous contact Olympic team sport that places emphasis on running, jumping, sprinting, arm throwing, hitting, blocking, and pushing (Buchheit et al., 2009). Although physical and physiological characteristics related to handball performance have been extensively studied, the investigation of key factors and characteristics that can distinguish high-class and low-class players is continually ongoing among practitioners and scientists (Nikolaidis \& Ingebrigtsen, 2013). However, the proportion of research related to psychophysiological characteristics of handball players is relatively small, thus providing sparse information (Kajtna, Vuleta, Pori, Justin, \& Pori, 2012). The reaction time tasks used in psychology as a means to study mental processes and their underlying structures (Niemi \& Naatanen, 1981) can be used in order to determine neuro-cognitive characteristics relevant for performance in handball.

In reference to the previous and considering the fact that reaction time is an indirect index of the processing capability of the central nervous system and a simple means of determining sensory-motor association and performance of an individual (Das, Gandhi, \& Modal, 1997) it can be considered a suitable basic indicator for the evaluation of neurosensory and cognitive (attention) characteristics relevant in the selection and training of young athletes.

The most basic neuro-cognitive characteristic relevant to handball performance is reaction time. Reaction time, whether considering simple or more complex reactions, can be defined as the time elapsed between the presentation of a sensory stimulus and the subsequent behavioral response (Shelton \& Kumar, 2010). The simple reaction time task, such as the one used in this research, measures simple reaction time, general alertness and motor speed through a delivery of a known stimulus to a known location to elicit a known response (CANTAB, n.d.), and can be considered a basic indicator of the perceptual, cognitive and motor status of an individual. The results of previous studies have shown that differences in simple visual reaction time are significant in relation to several important factors such as age, intelligence, practice, type of stimulus etc. (Parlić et al., 2018; Ilić, 2015; Der \& Deary, 2006; Fontani, Lodi, Felici, Migliorini, \& Corradeschi, 2006; Ando, Kida, \& Oda, 2002, 2004; Jevas \& Yan, 2001; Nettelbeck, 1980; Welford, 1977), and the same seems to be true when considering choice reactions that are underpinned by more complex decision making (Schmidt \& Lee, 1998). The second neuro-cognitive characteristic relevant for sports, i.e. handball performance, is concentration, which can be defined as the ability to perform a task with a clear and present focus of attention (Vernacchia, 2003), which can be either internal or external and broad or narrow. During competitions, athletes are often called upon to shift across these dimensions in order to meet the required attentional demands of the situation ("Concentration and attention in sport", 2014). The overlapping nature of these dimensions leads to the need for attentional control, i.e. conscious focus concentration. Considering the specific demands that modern handball imposes on each player, and the chronic effects of regular training on reaction time (Marković \& Dopsaj, 2018), it is logical to assume that the differences regarding reaction time characteristics exist in relation to player position.

The aim of this paper is to define differences in Simple Visual Reaction Time (SVRT) and Reaction Time Variation (RTV), i.e. neuro-visual response and acute concentration, related to age and player position in Serbian female cadet and junior national handball 
team members, thus widening the fundus of scientific knowledge concerning the selection and preparation of team sports athletes, i.e. more specifically, female handball players.

\section{Methods}

The method used in this research was laboratory testing. All data sampling was performed using specially designed testing software that recorded reaction time with $1 \mathrm{~ms}$ precision and was developed in Labview 2012 software surroundings.

\section{The research sample}

The research sample in this study consisted of a total of 34 participants, of which 19 cadet and 15 junior players. All of the participants were members of the Serbian national handball team for their respective age. Mean age was $15.71 \pm 0.75$ and $17.56 \pm 0.79$ years for the cadet and the junior sample, respectively. All of the participants were involved in regular physical training, were healthy and had good vision. Seven players were left handed while 27 were right handed.

\section{Measurement protocols}

Before taking part in this research, all of the participants (parents for the participants under the age of 18) read and signed an informed consent form. All of the participants and their coaches were informed in detail about the measurement procedures and the possible risks and benefits of this research. This study was conducted in accordance with the postulates of the Declaration of Helsinki and was approved by the Ethics Committee of the University of Belgrade, Faculty of Sport and Physical Education. All of the tests were performed at the University of Belgrade, Faculty of Sport and Physical Education in Methodological research laboratory (MIL), between 9:00 AM and 11:30 AM. Before the testing began, the procedure was thoroughly explained and demonstrated to all the participants, who were then further familiarized with the testing procedure and equipment by performing two trial attempts. The testing procedure consisted of 5 consecutive trials, i.e., reactions. For each trial, visual stimulus $(15 \mathrm{~cm}$ diameter green dot appeared on a gray background) was presented on a laptop screen in a randomized time interval between 5 and $15 \mathrm{~s}$. On the appearance of a signal, the participants had to react as quickly as possible by pressing the corresponding mouse button with the index finger of their dominant hand. Reaction time lower than $120 \mathrm{~ms}$ was discarded as an error, and was substituted by an additional trial. The participants were instructed to avoid any strenuous physical activity prior to testing and did not perform any type of warm-up.

\section{Variables}

The variables used in this research, i.e. Simple Visual Reaction Time (SVRT) and Reaction Time Variation (RTV) were calculated as a mean value from 3 trials with the shortest reaction time taken from 5 consecutive trials. For the SVRT variable the achieved result was expressed in ms, while RTV was expressed as a coefficient of variation percentage value. 


\section{Statistical analysis}

In the first step of processing, all the raw data was subjected to descriptive statistical analysis in order to define the basic measure of central tendency (Mean), measures of data dispersion (SD, $\mathrm{cV} \%$ ) and data span indicators (Min, Max). The normality of the distribution of the results was determined by the application of the Shapiro-Wilk goodness of fit test. Statistical significance of the general differences between the tested subsamples was determined using the Factorial ANOVA in relation to age category and position of the tested handball players, while post hoc tests using the LSD criterion were used for pairwise comparisons, i.e. to determine the significance of the partial differences between respective subgroups. Principal component analysis was used to define standardized factor scores after which mathematical modeling, i.e. multidimensional scaling, was used in order to transform the factor score of each participant into a mathematical analogy, i.e. into a proportional score on a linear scale from 0 (hypothetical minimum) to 100 (hypothetical maximum) points (Dopsaj, 2015; Dopsaj, Ćopić, Nešić, \& Sikimić, 2010). The final form of the model was defined by application of a Multivariate Regression Analysis (MRA), where the value of the point score represented the criterion variable, and the results of the examined variables represented a system of predictor variables. All analysis were conducted using Microsoft Office Excel 2007 and IBM SPSS v23.0 statistical software. The level of statistical significance was defined based on the criterion $\mathrm{p} \leq 0.05$ (Hair, Anderson, Tatham, \& Black, 1998).

\section{RESULTS}

Table 1 Descriptive statistics for the Simple Visual Reaction Time and Reaction Time Variation variables in relation to age category of the tested players

\begin{tabular}{|c|c|c|c|c|c|c|c|c|c|}
\hline \multicolumn{10}{|c|}{ Descriptive Statistics } \\
\hline \multicolumn{10}{|c|}{ Overall } \\
\hline & $\mathrm{N}$ & Mean & Std.Err. & Std.Dev. & $\mathrm{cV}$ & Min. & Max. & Skew. & Kurt. \\
\hline SVRT (in ms) & 34 & 190.07 & 2.92 & 17.05 & 8.97 & 153.33 & 218.33 & -0.225 & -0.531 \\
\hline RTV (in \% & 34 & 6.13 & 0.58 & 3.40 & 55.38 & 1.23 & 14.28 & 0.663 & -0.070 \\
\hline \multicolumn{10}{|c|}{ Cadet } \\
\hline & $\mathrm{N}$ & Mean & Std.Err. & Std.Dev. & $\mathrm{cV}$ & Min. & Max. & Skew. & Kurt. \\
\hline SVRT (i & 19 & 194.28 & 3.80 & 16.55 & 8.52 & 164.00 & 218.33 & -0.078 & -1.005 \\
\hline RTV (in \%) & 19 & 4.74 & 0.55 & 2.41 & 50.96 & 1.23 & 9.28 & 0.287 & -1.061 \\
\hline \multicolumn{10}{|c|}{ Junior } \\
\hline & $\mathrm{N}$ & Mean & Std.Err. & Std.Dev. & $\mathrm{cV}$ & Min. & Max. & Skew. & Kurt. \\
\hline SVRT (in ms) & 15 & 184.73 & 4.31 & 16.68 & 9.03 & 153.33 & 209.00 & -0.499 & -0.617 \\
\hline RTV (in \%) & 15 & 7.90 & 0.96 & 3.70 & 46.87 & 2.29 & 14.28 & 0.214 & -0.792 \\
\hline
\end{tabular}

Table 2 Results of the Shapiro-Wilk goodness of fit test in relation to age category of the tested players

\begin{tabular}{|c|c|c|c|c|c|c|c|c|c|}
\hline \multicolumn{10}{|c|}{ Shapiro-Wilk Test of Normality } \\
\hline & \multicolumn{3}{|c|}{ Overall } & \multicolumn{3}{|c|}{ Cadet } & \multicolumn{3}{|c|}{ Junior } \\
\hline & Statistic & $\mathrm{df}$ & Sig. & Statistic & $\mathrm{df}$ & Sig. & Statistic & $\mathrm{df}$ & Sig. \\
\hline$\overline{\text { SVRT }}$ & 0.977 & 34 & 0.682 & 0.954 & 19 & 0.453 & 0.958 & 15 & 0.663 \\
\hline RTV & 0.945 & 34 & 0.089 & 0.951 & 19 & 0.413 & 0.952 & 15 & 0.559 \\
\hline
\end{tabular}


Table 3 Results of the Factorial analysis of the variance (Factorial ANOVA) indicating the significance of general differences between the tested groups in relation to SVRT and RTV variables

\begin{tabular}{|c|c|c|c|c|c|c|c|}
\hline \multicolumn{8}{|c|}{ Tests of Between-Subjects Effects } \\
\hline \multicolumn{8}{|c|}{ SVRT } \\
\hline & $\begin{array}{l}\text { Sum of } \\
\text { Squares }\end{array}$ & $\mathrm{df}$ & $\begin{array}{c}\text { Mean } \\
\text { Square }\end{array}$ & $\mathrm{F}$ & Sig. & $\begin{array}{c}\text { Partial } \\
\mathrm{Eta}^{2}\end{array}$ & $\begin{array}{c}\text { Observed } \\
\text { Power }\end{array}$ \\
\hline Age Category & 465.630 & 1 & 465.630 & 1.288 & 0.269 & 0.058 & 0.192 \\
\hline Position & 274.393 & 6 & 45.732 & 0.126 & 0.992 & 0.035 & 0.074 \\
\hline Age Category * Position & 1007.450 & 5 & 201.490 & 0.557 & 0.731 & 0.117 & 0.168 \\
\hline \multicolumn{8}{|c|}{ RTV } \\
\hline & $\begin{array}{l}\text { Sum of } \\
\text { Squares }\end{array}$ & df & $\begin{array}{c}\text { Mean } \\
\text { Square }\end{array}$ & $\mathrm{F}$ & Sig. & $\begin{array}{c}\text { Partial } \\
\mathrm{Eta}^{2}\end{array}$ & $\begin{array}{c}\text { Observed } \\
\text { Power }\end{array}$ \\
\hline Age Category & 69.106 & 1 & 69.106 & 9.752 & 0.005 & 0.317 & 0.845 \\
\hline Position & 71.864 & 6 & 11.977 & 1.690 & 0.173 & 0.326 & 0.510 \\
\hline Age Category * Position & 78.892 & 5 & 15.778 & 2.227 & 0.090 & 0.346 & 0.603 \\
\hline
\end{tabular}

Table 4 Pairwise comparisons for the SVRT and RTV variables in relation to team position of the tested players

\begin{tabular}{|c|c|c|c|c|c|c|c|}
\hline \multicolumn{8}{|c|}{ Pairwise Comparisons } \\
\hline \multicolumn{2}{|c|}{ Dependent Variable: } & \multicolumn{3}{|c|}{ SVRT } & \multicolumn{3}{|c|}{ RTV } \\
\hline Position & & Mean Diff. & Std. Error & Sig. & Mean Diff. & Std. Error & Sig. \\
\hline \multirow[t]{6}{*}{ Right wing } & Left wing & -3.167 & 15 & 0.835 & 0.300 & 2.105 & 0.888 \\
\hline & Right back & -3.139 & 15 & 0.831 & 3.977 & 2.033 & 0.064 \\
\hline & Left back & 3.111 & 12 & 0.797 & 1.814 & 1.675 & 0.291 \\
\hline & Pivot & 4.611 & 13 & 0.724 & 4.933 & 1.802 & 0.012 \\
\hline & Goalkeeper & 7.306 & 12 & 0.558 & 0.995 & 1.718 & 0.569 \\
\hline & Center back & 2.000 & 13 & 0.875 & 1.309 & 1.761 & 0.466 \\
\hline \multirow[t]{6}{*}{ Left wing } & Right wing & 3.167 & 15 & 0.835 & -0.300 & 2.105 & 0.888 \\
\hline & Right back & 0.028 & 16 & 0.999 & 3.677 & 2.240 & 0.116 \\
\hline & Left back & 6.278 & 14 & 0.652 & 1.515 & 1.921 & 0.439 \\
\hline & Pivot & 7.778 & 15 & 0.598 & 4.633 & 2.033 & 0.033 \\
\hline & Goalkeeper & 10.472 & 14 & 0.463 & 0.695 & 1.959 & 0.726 \\
\hline & Center back & 5.167 & 14 & 0.721 & 1.009 & 1.997 & 0.619 \\
\hline \multirow[t]{6}{*}{ Right back } & Right wing & 3.139 & 15 & 0.831 & -3.977 & 2.033 & 0.064 \\
\hline & Left wing & -0.028 & 16 & 0.999 & -3.677 & 2.240 & 0.116 \\
\hline & Left back & 6.250 & 13 & 0.640 & -2.163 & 1.843 & 0.254 \\
\hline & Pivot & 7.750 & 14 & 0.586 & 0.956 & 1.959 & 0.631 \\
\hline & Goalkeeper & 10.444 & 13 & 0.446 & -2.982 & 1.882 & 0.128 \\
\hline & Center back & 5.139 & 14 & 0.712 & -2.669 & 1.921 & 0.179 \\
\hline \multirow[t]{6}{*}{ Left back } & Right wing & -3.111 & 12 & 0.797 & -1.814 & 1.675 & 0.291 \\
\hline & Left wing & -6.278 & 14 & 0.652 & -1.515 & 1.921 & 0.439 \\
\hline & Right back & -6.250 & 13 & 0.640 & 2.163 & 1.843 & 0.254 \\
\hline & Pivot & 1.500 & 11 & 0.896 & 3.118 & 1.584 & 0.062 \\
\hline & Goalkeeper & 4.194 & 11 & 0.697 & -0.820 & 1.488 & 0.588 \\
\hline & Center back & -1.111 & 11 & 0.920 & -0.506 & 1.537 & 0.745 \\
\hline
\end{tabular}


Table 4 Pairwise comparisons for the SVRT and RTV variables in relation to team position of the tested players (continued)

\begin{tabular}{llcccccc}
\hline \multicolumn{7}{c}{ Pairwise Comparisons } \\
\hline Dependent Variable: & \multicolumn{3}{c}{ SVRT } & \multicolumn{3}{c}{ RTV } \\
\hline Position & & Mean Diff. & Std. Error & Sig. & Mean Diff. & Std. Error & Sig. \\
\hline Pivot & Right wing & -4.611 & 13 & 0.724 & -4.933 & 1.802 & 0.012 \\
& Left wing & -7.778 & 15 & 0.598 & -4.633 & 2.033 & 0.033 \\
& Right back & -7.750 & 14 & 0.586 & -0.956 & 1.959 & 0.631 \\
& Left back & -1.500 & 11 & 0.896 & -3.118 & 1.584 & 0.062 \\
& Goalkeeper & 2.694 & 12 & 0.819 & -3.938 & 1.630 & 0.025 \\
& Center back & -2.611 & 12 & 0.829 & -3.624 & 1.675 & 0.042 \\
\hline Goalkeeper & Right wing & -7.306 & 12 & 0.558 & -0.995 & 1.718 & 0.569 \\
& Left wing & -10.472 & 14 & 0.463 & -0.695 & 1.959 & 0.726 \\
& Right back & -10.444 & 13 & 0.446 & 2.982 & 1.882 & 0.128 \\
& Left back & -4.194 & 11 & 0.697 & 0.820 & 1.488 & 0.588 \\
& Pivot & -2.694 & 12 & 0.819 & 3.938 & 1.630 & 0.025 \\
& Center back & -5.306 & 11 & 0.644 & 0.314 & 1.584 & 0.845 \\
\hline Center back & Right wing & -2.000 & 13 & 0.875 & -1.309 & 1.761 & 0.466 \\
& Left wing & -5.167 & 14 & 0.721 & -1.009 & 1.997 & 0.619 \\
& Right back & -5.139 & 14 & 0.712 & 2.669 & 1.921 & 0.179 \\
& Left back & 1.111 & 11 & 0.920 & 0.506 & 1.537 & 0.745 \\
& Pivot & 2.611 & 12 & 0.829 & 3.624 & 1.675 & 0.042 \\
& Goalkeeper & 5.306 & 11 & 0.644 & -0.314 & 1.584 & 0.845 \\
\hline
\end{tabular}

Adjustment for multiple comparisons: Least Significant Difference

Table 5 The final form of regression equation for prediction and evaluation of neurovisual and cognitive status in relation to the respective variables

Point_score $=193.143-0.648 *$ SVRT-3.252*RTV

\section{DISCUSSION}

The results of the descriptive statistical analysis for the SVRT variable have shown an extremely high level of homogeneity (Perić, 2003) considering the overall $(8.97 \%)$, as well as the subsamples of cadet $(8.52 \%)$ and junior $(9.03 \%)$ players (Table 1). For the RTV variable the $\mathrm{cV} \%$ of the overall sample was $55.38 \%$, while for the subsamples of cadet and junior players it was 50.96 and $46.87 \%$, respectively (Table 1). These values indicate an average level of homogeneity (Perić, 2003), or a high level of homogeneity considering the fact that the RTV is a derived variable. The results of the Shapiro-Wilk test for the normality of the distribution have shown that the data was normally distributed for both variables, as well as the overall sample and both subsamples ( $p>0.05$ ) (Table 2). On the basis of the aforementioned, it can be concluded that the obtained results are normally distributed and have an adequate level of homogeneity which makes them representative in terms of further scientific processing and interpretation.

Considering the SVRT variable there is a consensus in the scientific literature that mean simple reaction time on a visual stimulus in humans is approximately 190-200 ms (Kosinski, 2008; Milošević, 2002). Although previous findings have shown that females have slower reaction time compared to males (Bleecker, Bola-Wilson, Agnew, \& Meyers, 
1987; Dane \& Erzurumluoglu, 2003; Der \& Deary, 2006) a trend of equation of reaction time between females and males has been reported by Silverman (2006). The results of our study have shown that tested female cadet handball players have an overall SVRT mean of $190.07 \pm 2.92 \mathrm{~ms}$ which is a slightly shorter RT compared to female ACPS (Academy of Criminalistic and Police Studies) students tested with the same methodology who had a mean SVRT of 202.30 \pm 18.89 ms (Marković, Vučković, \& Janković, 2019). The presented results of the overall sample as well as the results of the respective subsamples of cadet and junior players that have a SVRT mean value of $194.28 \pm 3.80$ and $184.73 \pm 4.31 \mathrm{~ms}$ can be directly compared with the results of moderately and highly active females who have mean SVRT values of $203.07 \pm 19.47$ and $191.68 \pm 16.57 \mathrm{~ms}$, respectively (Marković \& Dopsaj, 2018). These results further confirm previously established positive effects of physical training on neuro-visual, i.e. visual reaction characteristics in female participants. As for the RTV variable, the values determined for the overall sample were $6.13 \pm 0.58 \%$, while for the cadet and junior subsamples RTV was $4.74 \pm 0.55$ and $7.90 \pm 0.96 \%$. Considering the fact that RTV represents a cV\% percentage value, the previously stated values indicate an extremely high level of homogeneity of the results, i.e. reactions, in all cases, which further implies a high level of acute concentration. In the lack of similar data the presented results can be compared with the results calculated from the data obtained with the same methodology that was used in previous publications. When compared with female ACPS students, an RTV of $9.78 \pm 4.78 \%$ and active females that have an RTV at the level of 10.46 $\pm 7.23 \%$ (Marković \& Dopsaj, 2018; Marković et al., 2019) the RTV values found in the samples considered in this research indicate higher levels of acute concentration in trained participants. An explanation for shorter reaction time in physically active participants was proposed by Spirduso (1975) who points out to the possible positive relationship between augmented excitation and continuous demands for fast decision making during sports activities and enhanced neural efficiency, which can possibly also contribute to higher levels of acute concentration, i.e. voluntary attention focus.

The general differences in relation to SVRT were not statistically significant considering age $(\mathrm{F}=1.288, \mathrm{p}=0.269)$, position $(\mathrm{F}=0.126, \mathrm{p}=0.992)$, or the interaction of these factors $(\mathrm{F}=0.557, \mathrm{p}=0.731$ ) (Table 3$)$. For the RTV variable, general differences were found in relation to the age category $(\mathrm{F}=9.752, \mathrm{p}=0.005)$, while differences in relation to player position and interaction of these factors were not statistically significant $(\mathrm{F}=1.690, \mathrm{p}=0.173$ and $\mathrm{F}=2.227, \mathrm{p}=0.090$, respectively) (Table 3 ). This basically indicates a higher overall level of concentration in cadet players, although the differences may be a result of a higher level of motivation in laboratory testing conditions in younger players. Partial differences in relation to player position were not statistically significant $(\mathrm{p}>0.05)$ when considering SVRT, while RTV players on the pivot position have significantly lower RTV than right (Mean Diff. $=-4.933, \mathrm{p}=0.012$ ) and left wingers (Mean Diff. $=-4.633, \mathrm{p}=0.033$ ), goalkeepers (Mean Diff.=-3.938, $\mathrm{p}=0.025$ ) and center backs (Mean Diff.=-3.624, $\mathrm{p}=0.042$ ) (Table 4). This clearly indicates that pivot position imposes different cognitive, i.e. neuro-visual and attentional demands on players, although whether the origin of differences is related to selection or specific training is not clear. The most reasonable explanation involves the combination of the previously mentioned factors.

On the basis of the obtained results, the final form of the Point_Score prediction model was developed using methods of multidimensional scaling and a multivariate regression analysis (MRA) (Table 5). This model is intended for the evaluation and prediction of simple cognitive characteristics in elite female handball players in 
developmental stages of their sports career (Dopsaj, 2015; Koprivica, 2013). The influence of individual variables, i.e. SVRT and RTV on the general score in the model can be viewed through the values of coefficients obtained using the Multivariate Regression Analysis $($ MRA) $($ SVRT Coefficient $=-0.648$, RTV Coefficient $=-3.252)($ Table 5) and the average values $($ SVRT Mean value $=190.07 \pm 17.05 \mathrm{~ms}$, RTV Mean value $=6.13 \pm 3.40 \%)($ Table 1$)$ of the results obtained for both variables. It is obvious that neuro-visual reaction capabilities influence the final positioning of the participants more than the level of attention focus. Although at first sight this seems in line with the characteristics of the game of handball that is composed of subsequent intervals of high and low speed game execution (Póvoas et al., 2012), further research is needed in order to draw any definite conclusions on the matter.

In all, this initial research on the cognitive, that is, reaction characteristic of handball players opens the field for further studies necessary to determine the type of load, i.e., the complexity of the visual reaction time task with a sufficient discriminatory value in relation to the demands of modern handball training and selection.

\section{CONCLUSION}

This paper is aimed to determine the differences in Simple Visual Reaction Time (SVRT in s) and Reaction Time Variation (RTV in \%), i.e. neuro-visual response and acute concentration, related to age and player position in Serbian female cadet and junior national handball team members. The method used in this research was laboratory testing. All data sampling was performed using specially designed testing software that recorded visual reaction time with $1 \mathrm{~ms}$ precision. SVRT and RTV were calculated from 3 trials with the shortest reaction time from 5 consecutive trials. SVRT was expressed in ms, and RTV was expressed as a coefficient of variation percentage value. The sample in this research included a total of 34 players, further divided into two subsamples - cadets $(\mathrm{N}=19)$ and juniors $(\mathrm{N}=15)$. The overall mean SVRT was at the level of $190.07 \pm 2.92 \mathrm{~ms}$ while Mean SVRT of $194.28 \pm 16.55$ and $184.73 \pm 16.68 \mathrm{~ms}$ was determined in the subsamples of cadet and junior players, respectively. It was found that cadets have a mean RTV of $4.74 \pm 2.41 \%$ while juniors have a mean RTV of $7.90 \pm 3.70 \%$. The overall RTV was at the level of $6.13 \pm 0.58 \%$. The analyses of differences included a Factorial ANOVA that has shown no general, statistically significant, differences in SVRT in relation to age, player position, and interaction of previous factors $(p>0.05)$. Statistically significant difference in RTV on a general level was found in relation to age only $(\mathrm{F}=9.752, \mathrm{p}=0.005)$, while differences in relation to player position or combination of these factors were not statistically significant $(p>0.05)$. Following post hoc tests have shown partial differences in RTV $(p<0.05)$, that is, significant differences between players on the pivot position and 4 other player positions (right and left wingers, goalkeepers and center backs). The method of mathematical modelling, i.e. multidimensional scaling, followed by a multivariate regression analysis (MRA) was used to define the statistical model of performance in relation to the simple cognitive characteristics of elite female handball players. The final form of the model explained $100 \%$ of measured variance $(\operatorname{AdjR} 2=1.000)$, which implies its absolute predictive potential considering the characteristics of the sample. The standard error of the resulting predictive Point_Score was minor (0.00005 points). Further research on a larger sample that would include fully developed athletes, i.e. national A team members, is necessary to determine the type of load and the complexity of the visual reaction time task with sufficient discriminatory value in relation to the demands of modern handball selection. 


\section{LIMITATIONS}

Although this research was conducted on elite female handball players for their respective age, that is, members of the national team of the Republic of Serbia, it should be noted that the overall sample and the examined subsamples were relatively small. This points to the need for further research that would include a larger sample and, ideally, national A team members.

Acknowledgments: The paper is a part of the project "Effects of the Applied Physical Activity on Locomotor, Metabolic, Psychosocial and Educational Status of the Population of the Republic of Serbia”, number III47015, funded by the Ministry of Education, Science and Technological Development of the Republic of Serbia - Scientific Projects 2011 - 2019 Cycle.

\section{REFERENCES}

Ando, S., Kida, N., \& Oda, S. (2002). Practice effects on reaction time for peripheral and central visual fields. Perceptual and Motor Skills, 95, 747-752.

Ando, S., Kida, N., \& Oda, S. (2004). Retention of practice effects on simple reaction time for peripheral and central visual fields. Perceptual and Motor Skills, 98, 897-900.

Bleecker, M.L., Bola-Wilson, K., Agnew, J., \& Meyers, D.A. (1987). Simple visual reaction time: Sex and age differences. Developmental Neuropsychology, 3(2), 165-172.

Buchheit, M., Laursen, P., Kuhnle, J., Ruch, D., Renaud, C., \& Ahmaidi, S. (2009). Game-based training in young elite handball players. International Journal of Sports Medicine, 30(4), 251-258.

CANTAB. (n.d.). Retrieved September 5, 2018, from the World Wide Web: http://www.cambridgecognition. com/cantab/

Concentration and attention in sport. (2014). Retrieved March 7, 2019, from the World Wide Web: https://www.apadivisions.org/division-47/publications/sportpsych-works/concentration-and-attention.pdf

Dane, S., \& Erzurumluoglu, A. (2003). Sex and handedness differences in eye-hand visual reaction times in handball players. International Journal of Neuroscience, 113(7), 923-929.

Das, S., Gandhi, A., \& Mondal, S. (1997). Effect of premenstrual stress on audiovisual reaction time and audiogram. Indian Journal of Physiology and Pharmacology, 41(1), 67-70.

Der, G., \& Deary, I. J. (2006). Age and sex differences in reaction time in adulthood: Results from the United Kingdom health and lifestyle survey. Psychology and Aging, 21(1), 62-73.

Dopsaj, M. (2015). Analitika i dijagnostika u sportu i fizičkom vaspitanju (Analytics and diagnostics in sports and physical education). Belgrade: Faculty of Sport and Physical Education, University of Belgrade. In Serbian

Dopsaj, M., Ćopić, N., Nešić, G., \& Sikimić, M. (2010). A simple mathematical model for estimating general jumping preparedness of senior female volleyball players. Exercise and Quality of Life, 2(2), 63-74.

Fontani, G., Lodi, L., Felici, A., Migliorini, S., \& Corradeschi, F. (2006). Attention in athletes of high and low experience engaged in different open skill sports. Perceptual and Motor Skills, 102, 791-816.

Hair, J., Anderson, R., Tatham, R., \& Black, W. (1998). Multivariate data analysis with readings (5th ed.). New Jersey: Prentice-Hall International, Inc.

Ilić, I. (2015). Structures and differences of the cognitive abilities of top handball, volleyball, basketball and soccer players. Facta Universitatis Series Physical Education and Sport, 403-410.

Jevas, S., \& Yan, J.H. (2001). The effect of aging on cognitive function: a preliminary quantitative review. Research Quarterly for Exercise and Sport, 72, A-49.

Kajtna, T., Vuleta, D., Pori, M., Justin, I., \& Pori, P. (2012). Psychological characteristics of Slovene handball goalkeepers. Kinesiology, 44(2), 209-217.

Koprivica, V. (2013). Teorija sportskog treninga (Theory of sports training). Belgrade: Autonomous edition of the author.

Kosinski, R.J. (2008). A literature review on reaction time. Retrieved from the World Wide Web: http://www.cognaction.org/cogs105/readings/clemson.rt.pdf

Marković, S., \& Dopsaj, M. (2018). Simple visual reaction time: differences in relation to gender and level of physical activity in Serbian young adults - pilot study. In M. Kocić (Ed.), FIS Communications (pp. 221228). University of Niš Faculty of Sport and Physical Education. 
Marković, S., Vučković, G., \& Janković, R. (2019). Simple visual reaction time in students of the Academy of Criminalistic and Police Studies: Initial standard values and gender-based differences. Bezbednost, 61(1), 33-48.

Milošević, S. (2002). Percepcija, pažnja i motorna aktivnost (Perception, attention and motor activity). Belgrade: Zavod za udžbenike i nastavna sredstva. In Serbian

Nettelbeck, T. (1980). Factors affecting reaction time: Mental retardation, brain damage, and other psychopathologies. In A.T. Welford (Ed.), Reaction times, (pp. 355-401). New York: Academic Press

Niemi, P., \& Naatanen, R. (1981). Foreperiod and simple reaction time. Psychological Bulletin, 89(1), 133-162.

Nikolaidis, P.T., \& Ingebrigtsen, J. (2013). Physical and physiological characteristics of elite male handball players from teams with a different ranking. Journal of Human Kinetics, 38(1), 115-124.

Parlić, M., Ilić, A., Jakšić, V., Parlić, M., Makević, V., \& Milanović, S. (2018). The study of the age-related dynamics of the reaction time to visual stimuli in schoolchildren. Facta Universitatis Series Physical Education and Sport, 337-346.

Perić, D. (2003). Statistika primenjena u sportu i fizičkom vaspitanju (Statistics used in sports and physical education). Belgrade: Faculty of Sport and Physical Education, University of Belgrade. In Serbian

Póvoas, S.C.A., Seabra, A.F.T., Ascensão, A.A.M.R., Magalhães, J., Soares, J.M.C., \& Rebelo, A.N.C. (2012). Physical and physiological demands of elite team handball. Journal of Strength and Conditioning Research, 26(12), 3365-3375.

Schmidt, R., \& Lee, T. (1998). Motor control and learning. Champaign: Human Kinetics.

Shelton, J., \& Kumar, G.P. (2010). Comparison between Auditory and Visual Simple Reaction Times. Neuroscience and Medicine, 1(1), 30-32.

Silverman, I.W. (2006). Sex differences in simple visual reaction time: a historical meta-analysis (sports events). Sex Roles: A Journal of Research, 54(1-2), 57-69.

Spirduso, W. W. (1975). Reaction and movement time as a function of age and physical activity level. Journal of Gerontology, 30(4), 435-440.

Vernacchia, R. A. (2003). Inner strength : the mental dynamics of athletic performance. Palo Alto: Warde Publishers.

Welford, A.T. (1977). Motor performance. In J.E. Birren \& K.W. Schaie (Eds.), Handbook of the Psychology of Aging, (pp. 450-496). New York: Van Nostrand Reinhold.

\section{RAZLIKE KARAKTERISTIKA VIZUELNOG REAGOVANJA KOD KADETSKIH I JUNIORSKIH IGRAČICA RUKOMETA NACIONALNOG NIVOA}

Cilj ovog rada je definisanje razlika u vremenu reagovanja na jednostavan vizuelni stimulus (SVRT) $i$ varijaciji vremena reagovanja (RTV), odnosno neurovizuelnog odgovora i akutne koncentracije, vezanih za uzrast i poziciju igračica kod članova kadetske i juniorske selekcije ženskog rukometnog tima R. Srbije. $U$ ovom istraživanju je korišćen metod laboratorijskog testiranja. Uzorkovanje podataka je izvršeno korišćenjem specijalno dizajniranog softvera koji registruje vreme vizuelne reakcije na nivou preciznosti od Ims. SVRT je izražen u ms, dok je RTV izražen kao procentualna vrednost koeficijenta varijacije rezultata. Ukupni uzorak se sastojao od 34 igračice - 19 kadetkinja i 15 juniorki. Prosečna vrednost SVRT od 194.28 16.55 i $184.73 \pm 16.68$ ms je utvrdena na uzorcima kadetkinja I juniorki, respektivno. Utvrđeno je da kadetkinje imaju prosečan RTV od $4.74 \pm 2.41 \%$ dok juniorke imaju proseečan RTV na nivou 7.90 3.70\%. Rezultati Faktorske ANOVE su pokazali da ne postoje generalne statistički značajne rezlike SVRT u odnosu na uzrast, poziciju igračica, ili interakciju ovih faktora ( $p>0.05)$. Statistički značajne razlike RTV na generalnom nivou nađene su samo u odnosu na uzrast $(F=9.752, p=0.005)$, dok razlike u odnosu na poziciju igračica i interakciju ovih faktoranisu nisu bile statistički značajne ( $p>0.05$ ). Post hok testovi su pokazali postojanje parcijalnih razlika u odnosu na poziciju igračica. Metoda matematičkog modelovanja je korišćena za definisanje statističkog modela uspešnosti u funkciji zadatih varijabli. Finalna forma modela je objasnila 100\% izmerene varijanse (AdjR2 =1.000), što ukazuje na apsolutni prediktivni potencijal uzimajući u obzir karakteristike uzorka.

Ključne reči: rukomet, vreme reagovanja, koncentracija, uzrasna kategorija 